\title{
The manifold actions of the protein inhibitor of activated STAT proteins on the transcriptional activity of mineralocorticoid and glucocorticoid receptors in neural cells
}

\author{
M Tirard, J Jasbinsek, O F X Almeida and T M Michaelidis \\ Max Planck Institute of Psychiatry, Kraepelinstrasse 2-10, D-80804 Munich, Germany \\ (Requests for offprints should be addressed to O F X Almeida; Email: osa @ mpipsykl.mpg.de) \\ (T M Michaelidis is now at Department of Neuroscience, University of Innsbruck, Anichstrasse 35, A-6020 Innsbruck, Austria)
}

\begin{abstract}
Corticosteroid actions in the brain are exerted via the mineralocorticoid receptor (MR) and glucocorticoid receptor (GR). These receptors share several structural and functional similarities but their activation in the brain triggers distinct biological actions, for instance on neuronal survival or the regulation of the hypothalamo-pituitary-adrenal axis. Like other hormone-activated receptors, the transcriptional properties of the MR and GR depend on their ability to recruit a variety of co-regulators, which modulate their activity on target promoters, in a specific manner. The N-terminal regions of the MR and GR share the smallest degree of sequence conservation, whereas they display opposite effects on the transactivation properties of these receptors; thus, they may provide surfaces suitable for receptorspecific interactions with co-regulatory proteins. Here, we employed a yeast two-hybrid system to identify molecules interacting with the N-terminal part of the MR (amino acids 170-433). This approach resulted in the isolation of representative cDNAs from all members of the protein inhibitor of activated STAT (PIAS) family of proteins as potential MR-interacting partners. In neural cells, PIAS3 exhibited a strong and specific interaction with MR, but not GR, as indicated by mammalian two-hybrid assays and co-immunoprecipitation experiments in vivo. The interaction with MR was enhanced in the presence of aldosterone, an MR agonist, and was found to occur through a conserved, serine- and acidic amino acid residue-rich domain of PIAS3. To compare the modulatory properties of PIAS proteins on MR and GR transcriptional activity in a neural environment, MMTV reporter gene assays were performed in the human neuroblastoma cell line SK-N-MC. This analysis revealed that PIAS3 can inhibit MR, but not GR, transactivation in response to their corresponding ligands. Further, it showed that PIAS1 and PIASx $\beta$, but not PIASy, could also inhibit MR-mediated transcription despite the lack of detected physical interaction with MR. Interestingly, PIASx $\beta$ and PIASy dose-dependently co-activated GR, whereas PIAS1 impaired GR-induced transcription. Taken together the results reveal differential modulatory roles of the PIAS proteins on the transcriptional properties of MR and GR, thus providing new insights into the bifurcating actions of these two receptors in neural cells where they are frequently co-localized.
\end{abstract}

Journal of Molecular Endocrinology (2004) 32, 825-841

\section{Introduction}

The mineralocorticoid receptor (MR) and glucocorticoid receptor (GR) regulate diverse functions, ranging from cellular physiology to behavior. In the brain, GRs are ubiquitously distributed, whereas MRs are more discretely expressed, mainly in areas involved in mood, cognition and neuroendocrine regulation (Roland et al. 1995). The hippocampus is one brain region in which MRs are expressed strongly; often, MR and GR may co-exist in the same cell (van Steensel et al. 1996). At physiological concentrations, the adrenal hormone corticosterone binds to and saturates MRs, whereas GRs only 
become occupied at the peak of the circadian rhythm of adrenocortical activity or during stress; interestingly, the receptors show only a 7- to 10-fold difference in their affinity for corticosterone (Reul \& de Kloet 1985). Apart from binding a common ligand, MR and GR apparently bind to identical hormone response elements on DNA but, nevertheless, their activation can trigger distinct, or even opposite, cellular responses. The concept that homeostasis in the brain is maintained through a fine balance between MR and GR activity (de Kloet et al. 1998) has been supported by both physiological and pathophysiological findings. For example, whereas activation of GR stimulates apoptosis in the dentate gyrus, MR activation counteracts GR-mediated cell death and appears to be essential for the survival of granule cells in this hippocampal subfield (Sloviter et al. 1993, Almeida et al. 2000, Sousa \& Almeida 2002). Work by Joëls and colleagues has shown that changes in $\mathrm{Ca}^{2+}$ flux and expression of $\mathrm{Ca}^{2+}$ channels may, at least partly, account for these differential effects of corticosteroids on hippocampal cell survival (Nair et al. 1998, Joëls 2001). Contrasting MR- and GR-mediated effects are also seen at the electrophysiological (Joëls 2000) and behavioral (de Kloet et al. 1999, McGaugh \& Roozendaal 2002) levels. Thus, despite several similarities in structure and pharmacological properties, MR and GR generally counteract each other's effects, albeit through as yet undefined molecular mechanisms.

MR and GR are members of the nuclear receptor (NR) superfamily, which upon occupation by ligand translocate to the nucleus where they bind as homoor heterodimers to specific response elements within the promoters of targeted genes and modify their transcription rate. Typically, NRs comprise five or six functional domains $(\mathrm{A}-\mathrm{E} / \mathrm{F})$, which show variable degrees of homology (Gronemeyer \& Laudet 2002). The A/B domain found at the N-terminus contains the ligand-independent $\mathrm{AF}-1$ domain (activation function-1). The central $(\mathrm{C} / \mathrm{D})$ domain includes two DNA-binding zinc fingers, and nuclear localization signals. Besides providing the ligandbinding pocket, the $\mathrm{G}$-terminus $\mathrm{E} / \mathrm{F}$ domain is also crucial for receptor dimerization, heat shock protein association and hormone-dependent transactivation (activation function-2, AF-2) (Gronemeyer \& Laudet 2002). NR recruitment of co-regulators to the basal transcriptional machinery is now considered to be a key regulatory step in NR-mediated transcription.
Co-regulatory complexes are differentially utilized to activate or repress gene transcription in cell- and promoter-specific fashions (Glass \& Rosenfeld 2000, Rosenfeld \& Glass 2001, DeFranco 2002, Xu \& Li 2003). Acting in either a sequential and/or combinatorial manner, co-regulators can modulate gene expression by virtue of either their intrinsic histone acetylase, deacetylase, or protein methyltransferase activities, their ATP-dependent chromatinremodeling abilities and/or their recruitment of the basal transcription machinery. Little is known about co-regulator modulation of the transactivation properties of MR and GR in neurons, although a role for the established steroid receptor co-activator-1 (SRC-1) in MR- and GR-mediated transcription has been speculated upon (Meijer 2002). Differences in the transcriptional properties of MR and GR have been attributed to the structural divergence of the N-terminal parts, which show less than 15\% sequence homology. This region contains the AF-1 domain as well as additional motifs conserved in many nuclear receptors (Iniguez-Lluhi \& Pearce 2000). Previous studies have demonstrated opposite effects of the N-terminal domains of MR and GR on their transcriptional activity, on both natural (Pearce \& Yamamoto 1993, Derfoul et al. 2000) and synthetic promoters (Rupprecht et al. 1993, Liu et al. 1995), indicating that these regions may act as receptorselective protein interaction surfaces, capable of recruiting specific modulatory proteins. To identify such molecules we performed a yeast two-hybrid screening of a human brain cDNA library using a part of the N-terminal region of MR (amino acids 170433) containing the AF-1 domain as bait. The screen yielded 15 candidate clones, four of which were found to represent distinct members of the PIAS (protein inhibitor of activated STAT) family, namely PIAS1, PIAS3, PIASx $\beta$ and PIASy. Here we report that, although only PIAS3 associates with the MR and GR in neural cells, all of the isolated PIAS proteins can influence MR and GR transcriptional activity, in a distinct and receptor-type-specific manner.

\section{Materials and methods}

\section{Yeast two-hybrid screening}

The human (h) MR bait was expressed as a fusion with the lexA DNA binding domain in the DUAL-Hybrid vector (Dualsystems Biotech AG, Zürich, Switzerland). Various portions of the 
N-terminal part of the hMR protein were tested for autonomous activation of reporter genes by measuring growth on selection plates (absence of Trp, Leu and His) and assaying for $\beta$-galactosidase $(\beta$-gal) activity. This approach revealed that yeast cells expressing an hMR bait comprising the amino acids 170-433 did not grow on selection plates and were negative in the $\beta$-gal assay; this bait was therefore chosen to screen a human brain cDNA library (Clontech, Heidelberg, Germany). Colonies grown on the selection media plates were selected for LacZ gene transactivation by monitoring $\beta$-gal activity in filter assays. Several positive clones were isolated from $4.8 \times 10^{6}$ primary transformants. Prey plasmids were recovered from $\beta$-gal-positive colonies and subjected to sequence analysis.

\section{Plasmid construction}

The MR and GR expression vectors pRShMR (Arriza et al. 1987) and pRShGR (Hollenberg et al. 1987), as well as the steroid-responsive mouse mammary tumor virus promoter luciferase reporter (pMMTV-Luc), were generous gifts from $\mathrm{R} \mathrm{M}$ Evans (La Jolla, CA, USA). pVP16-mPIAS3 and pSG5-mPIAS3 were kindly provided by $\mathrm{H}$ Gronemeyer (Strasbourg, France). The pFLAGmPIAS 3 and pFLAG-PIASx $\beta$ expression plasmids were provided by $\mathrm{H}$ Gronemeyer and J J Palvimo (Helsinki, Finland) respectively; PGMV-HA-hGR was a generous gift from $\mathrm{T}$ Rein (Munich, Germany). The mammalian two-hybrid vectors used were pM, expressing the DNA-binding domain of Saccharomyces cerevisiae GAL4 protein, and pVP16, expressing the transcription activation domain of the herpes simplex virus VP16 (both from Clontech); pFR-luciferase (Stratagene, Heidelberg, Germany) was used as a reporter. The fragment EagI-AflI of the hMR cDNA was inserted into Bsp120I-XbaI of pEGFP-C3 (Clontech) to generate pEGFP-hMR. The MR cDNA was extracted from pEGFP-hMR using SalI-BclI (blunt) and inserted into the SalI-XhoI (blunt) sites of CMV-HA (Clontech) and of pM-GAL4 (Clontech). The fragment FspI-BsaI (blunt) of the hGR cDNA was inserted into the SmaI (blunt) of pM-GAL4 (Clontech). The AF-1 bait used in mammalian two-hybrid assays was designed to correspond to that used in the YTH screening (see above). Briefly, XmaI and XbaI restriction sites were inserted respectively, at the $5^{\prime}$ and $3^{\prime}$ ends of the primers, and the sequence amplified using pRShMR as template. This product was inserted into $\mathrm{pM}$ vector (Clontech). PIAS cDNAs were excised from the yeast vector pACT2 and inserted into pVP16 or pCMV-HA vectors as follows: PIASx $\beta$ was subcloned into the SfiI-BglII sites of pCMV-HA and into the BamHI-SalI sites of pVP16; PIASy was inserted into EcoRI-BglII of pCMV-HA, from which a pVP16 construct was then generated. PIAS1 from pACT2 was subcloned into the EcoRI-BglII sites of pCMV-HA and the EcoRI(blunt)-BamHI sites of pVP16.

\section{Cell culture and transfections}

Human neuroblastoma SK-N-MC cells were kindly provided by $\mathrm{T}$ Rein. The cells were maintained at $37{ }^{\circ} \mathrm{C}$ and $5 \% \mathrm{CO}_{2}$ in Dulbecco's modified Earle's medium (DMEM) (Invitrogen, Karlsruhe, Germany) containing 10\% fetal calf serum (FCS) (Invitrogen) and 1\% kanamycin. For luciferase reporter experiments, cells were seeded into 24 -well plates $\left(8 \times 10^{4}\right.$ cells per well $) 1$ day before transfection with $375 \mathrm{ng} /$ well of total DNA using jet-PEI (Polytransfection, Illkirch, France). Cells were maintained in DMEM containing 10\% charcoal-stripped FCS (Sigma, Deisenhofen, Germany). Twelve hours after transfection, cells were transferred to DMEM containing $1 \%$ charcoal-stripped FCS and treated with steroid receptor ligands (all from Sigma and dissolved in ethanol): aldosterone (ALDO) $\left(10^{-6} \mathrm{M}\right)$, spironolactone (SPIRO) $\left(10^{-5} \mathrm{M}\right)$ and dexamethasone (DEX) $\left(10^{-6} \mathrm{M}\right)$. Cells were harvested $12-24 \mathrm{~h}$ thereafter in $100 \mu \mathrm{l}$ lysis buffer (Promega, Mannheim, Germany) and centrifuged. The cleared supernatants were assayed for $\beta$-gal and luciferase activity. For $\beta$-gal detection, $10 \mu$ cellular extract were mixed with $100 \mu \mathrm{l} \beta$-gal buffer (60 mM Na $\mathrm{NPO}_{4}, 40 \mathrm{mM} \mathrm{NaH}{ }_{2} \mathrm{PO}_{4}, 10 \mathrm{mM}$ $\mathrm{KCl}, 1 \mathrm{mM} \mathrm{MgCl}_{2}, 2 \mathrm{mM} \quad \beta$-mercaptoethanol) and $\quad 20 \mu \mathrm{l} \quad 10 \mathrm{mg} / \mathrm{ml} \quad O$-nitrophenyl- $\beta$-Dgalactopyranoside (Sigma). The reaction was terminated with $50 \mu \mathrm{l} \mathrm{Na} \mathrm{CO}_{3}(1 \mathrm{M})$ and absorption was measured at $410 \mathrm{~nm}$. Luciferase activity was measured by mixing $30 \mu \mathrm{l}$ cellular extract with $50 \mu \mathrm{l}$ buffer containing $75 \mathrm{mM}$ Tris- $\mathrm{HCl}$ and $1 \mathrm{mM} \mathrm{MgCl} 2$ (pH 8). Substrate (D-luciferin; $1 \mathrm{mM}$ ) was automatically injected (Luminometer; Berthold Instruments, Bad Wildbad, Germany) and light 
emission was measured over 20 s. Protein concentrations were determined using the Lowry et al. (1951) method.

\section{Western blotting}

Cells were harvested by scraping in $150 \mu \mathrm{l}$ lysis buffer $(100 \mathrm{mM}$ Tris-HCl including $10 \%$ glycerol, $1 \mathrm{mM}$ EDTA, $5 \mathrm{mM} \mathrm{MgCl} 2,250 \mathrm{mM} \mathrm{NaCl}, 1 \%$ Nonidet P-40 and 1:50 protease inhibitor cocktail (Roche, Mannheim, Germany)). Samples were briefly sonicated on ice and lysates were cleared by centrifugation at $4{ }^{\circ} \mathrm{C}(16000 \mathrm{~g}, 15 \mathrm{~min})$. Proteins were resolved by electrophoresis on 8 or $6 \%$ SDS polyacrylamide gels and transferred onto Protran BA83 nitrocellulose membranes (Schleicher \& Schuell, Dassel, Germany). Membranes were blocked in PBS containing 5\% milk powder and $0.2 \%$ Tween-20, and incubated with specific antibodies. Primary antibodies used were rabbit anti-VP16 (Clontech; 1:200), rabbit anti-EGFP (Clontech; 1:200), rabbit anti-GR (M20; Santa Cruz Biotechnology, Heidelberg, Germany; 1:1000), mouse anti- $\alpha$-tubulin (Chemicon, Hofheim, Germany; 1:1000), mouse anti-HA (BabCo, Freiburg, Germany; 1:1000), and rabbit and mouse anti-FLAG (Sigma; 1:1000). Antigens were revealed by enhanced chemiluminescence (Amersham Biosciences, Braunschweig, Germany) after incubation with appropriate horseradish peroxidase-IgG conjugates (Amersham Biosciences).

\section{Immunoprecipitation}

SK-N-MC cells were transfected with either MR-HA, FLAG-mPIAS3 or FLAG-PIASx $\beta$ expression vectors ( $3 \mu \mathrm{g}$ each). Cells were harvested in ice-cold RIPA buffer (PBS, $0 \cdot 1 \%$ SDS, $1 \%$ Nonidet P-40, $0.5 \%$ sodium deoxycholate, containing protease inhibitors (Roche)), briefly sonicated and homogenized using a Dounce homogenizer. Homogenates were centrifuged $\left(15 \mathrm{~min}, 4^{\circ} \mathrm{C}\right.$ ) and the resulting lysates were pre-cleared by incubation with a mixture of Protein A and G beads (Roche) for $1 \mathrm{~h}$ at $4{ }^{\circ} \mathrm{C}$ on a rotator. Beads were pelleted by centrifugation $(30 \mathrm{~s}$ at $13000 \boldsymbol{g})$ and the supernatant was transferred to a new tube containing HA-agarose beads (Sigma) and incubated for $16 \mathrm{~h}$ at $4{ }^{\circ} \mathrm{C}$ on a rotating platform. Beads were collected by brief centrifugation and washed three times with $1 \times$ PBS supplemented with protease inhibitors. Beads were resuspended in $20 \mu \mathrm{l}$ RIPA buffer and analyzed by electrophoresis on 6\% acrylamide gels.

\section{Statistical analysis}

Where appropriate, data were subjected to one-way ANOVA followed by appropriate post hoc tests. The level of significance was set at $P \leq 0 \cdot 05$.

\section{Results}

\section{Identification of PIAS proteins as MR-binding proteins}

To identify potential MR-interacting partners, we used a yeast two-hybrid assay where a human cDNA library was screened for interaction with the N-terminal region. A bait comprising the first 579 residues of the MR protein exhibited an autonomous activation of the reporter genes resulting in high background in yeast, due to its strong transactivation properties. Based on a previous analysis of overlapping internal deletion hMR mutants in mammalian cells (Govindan \& Warriar 1998) we designed and tested progressive deletions of this region. Deletion of the first 170 amino acids also proved to have autonomous activity. Therefore, we subsequently deleted the region between residues 433 and 579; yeast cells expressing this bait (amino acids 170-433) did not grow on selection plates and were negative in the $\beta$-gal assay. Screening of a human brain cDNA library (5 million transformants) with this bait resulted in isolation of several distinct clones, the sequencing analysis of which revealed four overlapping cDNAs encoding for PIAS1 (Valdez et al. 1997, Liu et al. 1998), two for PIAS3 (Chung et al. 1997) and PIASy (Liu et al. 1998) and a single clone for PIASx $\beta$ (Wu et al. 1997, Liu et al. 1998). cDNAs encompassing the complete open reading frame for all PIAS proteins, except that of PIAS3, were among the isolated clones. There were no nucleotide mismatches between the sequences of these cDNAs and those reported previously (GenBank Accession numbers: AF077951, AB021868, AF077952 and AF077954 for PIAS1, PIAS3, PIASy and PIASx $\beta$ respectively). 


\section{Interaction of PIAS proteins with MR in mammalian cells}

To determine whether PIAS proteins are capable of associating with MR in mammalian cells, we fused the AF-1-containing region of the MR (170-433; same as that used in the yeast two-hybrid screen) to the DNA-binding domain of the GAL4 protein (pM-AF1), while the PIAS preys were fused to the activation domain of the VP16 protein of herpes simplex virus. In the case of PIAS3, the clones isolated from the yeast screening comprised only C-terminal portions of the protein. We therefore used a mouse full-length cDNA for PIAS3 (97\% homologous to the human sequence) as well as the smallest of the two human clones isolated, which lacks the first $443 \mathrm{~N}$-terminal amino acids of the protein (PIAS $\left.3 \Delta_{1-443}\right)$. Subsequently, mammalian two-hybrid assays were carried out in a human neuroblastoma cell line (SK-N-MC). The pM-AF1 plasmid was co-transfected along with each of the PIAS-VP16 fusions and a GAL4responsive reporter plasmid, and luciferase activity was measured (Fig. 1A). PIAS-VP16 fusion protein co-transfected with empty $\mathrm{pM}$ vectors activated the Gal4 reporter gene more strongly than the pM-AF-1 bait co-transfected with empty pVP16 vector. Thus, we estimated the degree of interaction between the MR bait and each of the PIAS proteins by the ratio of luciferase activity obtained in cells co-expressing the PIAS-VP16 fusion proteins and the $\mathrm{pM}-\mathrm{AF}-1$ bait relative to the luciferase activity obtained in cells co-transfected with empty $\mathrm{pM}$ vectors and PIAS-VP16 fusion proteins (referred as 'relative luciferase activity' in Figs 1 and 3). Unexpectedly, none of the PIAS proteins exhibited a significant interaction with the AF-1 domain of MR in this assay. Since immunoblot analysis showed that all PIAS-VP16 fusions were efficiently expressed, and at comparable levels, the lack of PIAS-MR interactions was evidently not due to inefficient expression of the transfected proteins (Fig. 1B).

The AF-1 domain of MR carries a strong transactivation function, which can be constitutively active in the absence of the hormone-binding domain and has a higher activity than the intact receptor (Govindan \& Warriar 1998). To exclude the possibility that the lack of interaction between the MR bait and PIAS proteins resulted from an altered conformation or inappropriate post- translational modification of the $\mathrm{AF}-1$ region (i.e. in the absence of the C-terminal portion of the receptor), we performed another set of mammalian two-hybrid experiments in which full-length $\mathrm{MR}$ was employed as bait; interaction levels between the MR bait and the PIAS preys were calculated as described for Fig. 1A. As shown in Fig. 1C, this approach revealed a selective interaction of MR with PIAS3, but not with the other members of the PIAS family. The interaction was enhanced in the presence of the MR agonist ALDO: the transcriptional activity of the GAL4-responsive promoter increased from 5- to 30-fold. This hormoneenhanced association of MR with PIAS3 was strongly attenuated by concomitant exposure to the MR antagonist, SPIRO, indicating that the MR must be in a transcriptionally competent conformation to display optimal interaction with PIAS3. Interestingly, the truncated PIAS3 clone, PIAS3 $\Delta_{1-443}$, retained its capacity to interact with $\mathrm{MR}$ in a ligand-enhanced manner, implying that the integrity of the conserved SP-RING (Siz/PIAS RING) domain (Hochstrasser 2001) is dispensable for the interaction with MR.

To further verify the specificity of the interaction described above, HA-tagged MR and full-length FLAG-tagged PIAS3 were transiently expressed in SK-N-MC cells, and extracts were immunoprecipitated with anti-HA coupled beads. The immunoprecipitates were separated on SDS polyacrylamide gels and analyzed by Western blot using anti-HA and anti-FLAG antibodies. As shown in Fig. 2A, PIAS3 was co-immunoprecipitated with MR, specifically in lysates from cells expressing both PIAS3 and MR (lane 3), but not in extracts from cells transfected with PIAS3 alone (lane 5). In each case, incubation of the lysates with the corresponding antibodies confirmed the expression of the transfected proteins (lanes 1 and 4). Finally, we were not able to detect any coimmunoprecipitation of MR with the other PIAS proteins in SK-N-MC cells, as exemplified for PIASx $\beta$ in Fig. 2B; this result is consistent with our observations from the mammalian two-hybrid experiments. Taken together, the above results indicate that MR and PIAS3 can form a specific complex in SK-N-MG neural cells, presumably through the serine- and acidic amino acid-rich (Ser/Ac) domain, which is located in the C-terminal region of the molecule; the latter is known to be essential for the interaction of PIAS3 
A

AF-1 domain of MR

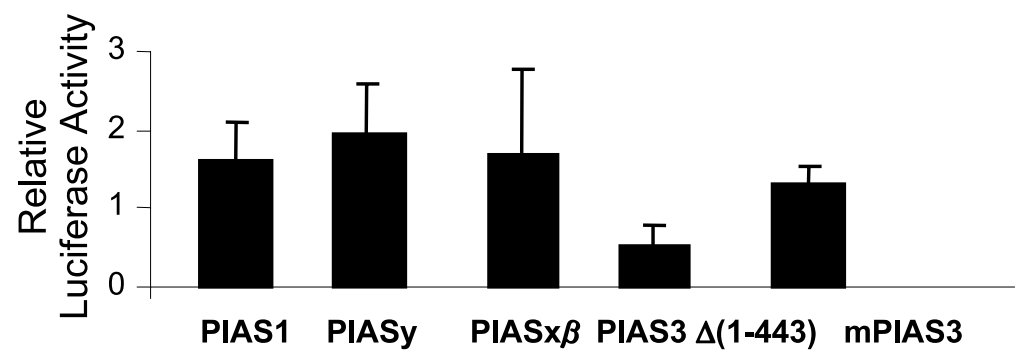

B

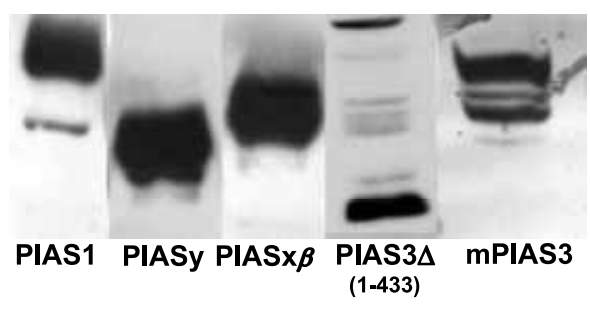

C

Full-length MR

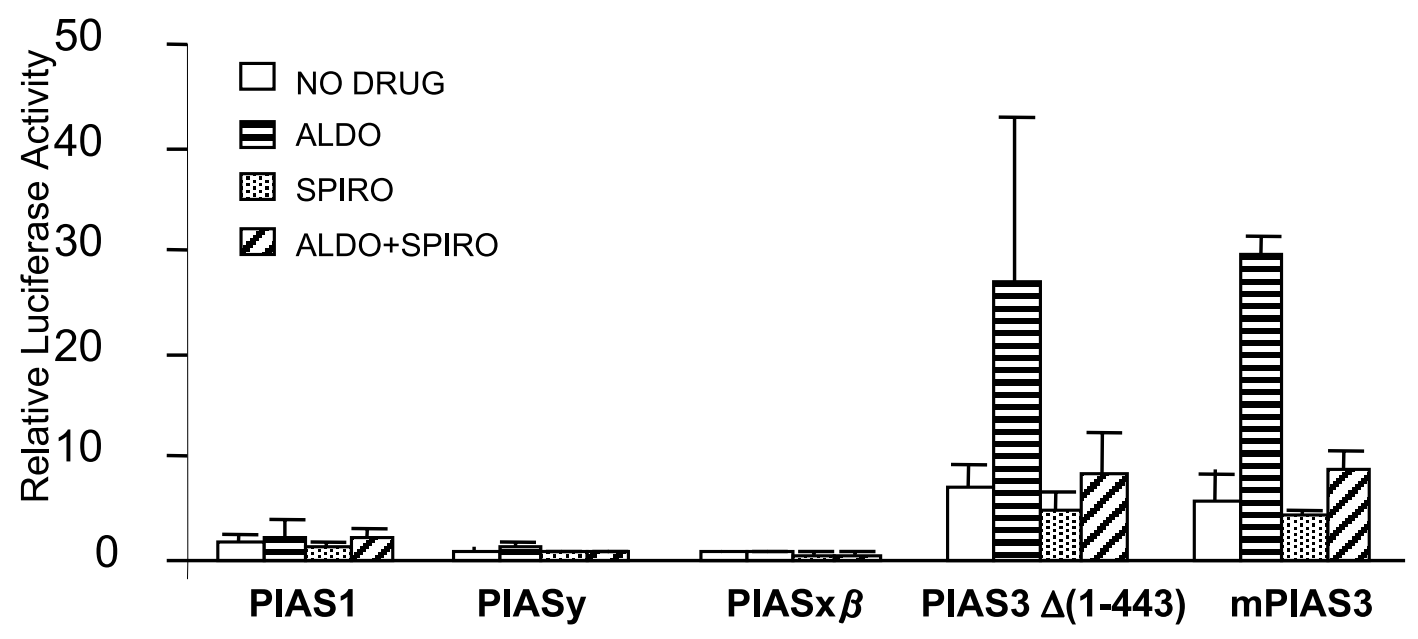


A

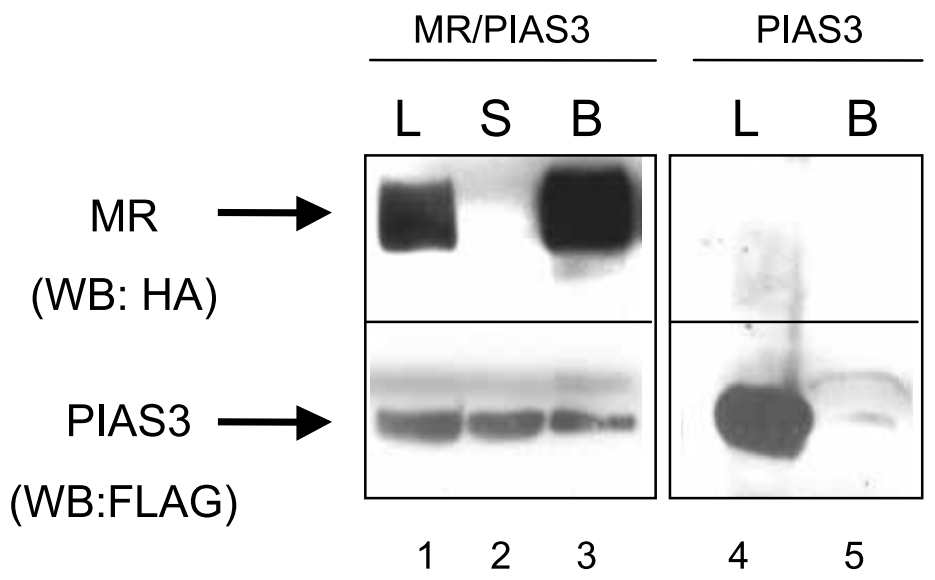

B
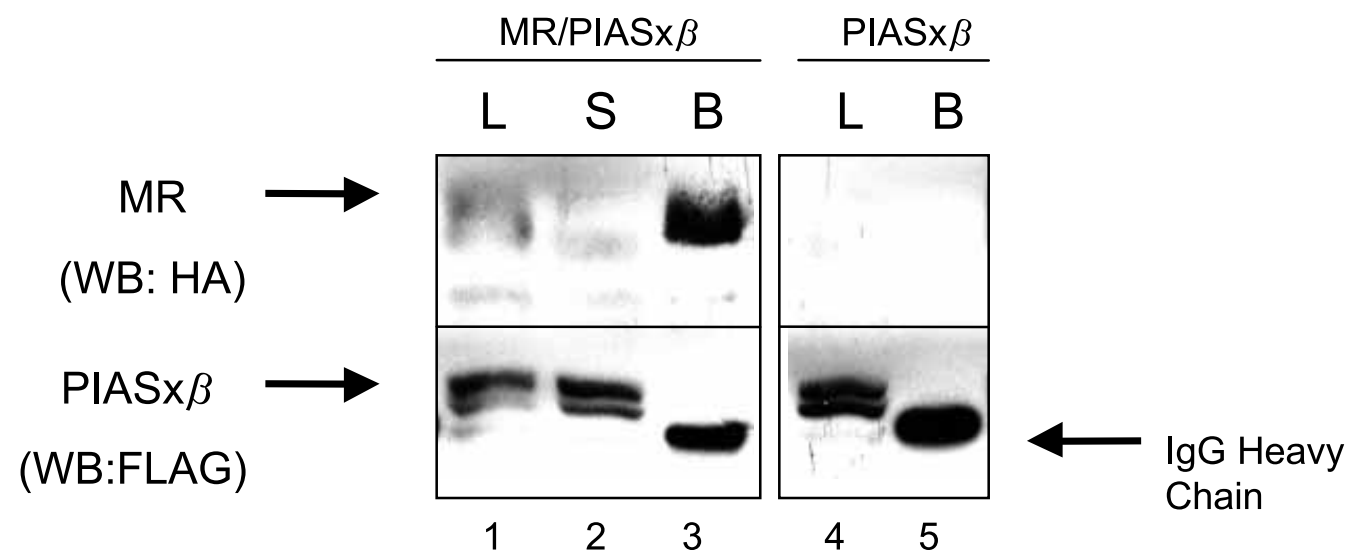

Figure 2 PIAS3, but not PIASx $\beta$, co-immunoprecipitate with MR in mammalian cells. SK-N-MC cells were transfected with $1.5 \mathrm{\mu g}$ of each of pCMV-HA-MR, pFLAG-mPIAS3 or pFLAG-PIASx $\beta$ expression vectors. pCMV-FLAG2 was used to keep levels of total transfected DNA constant. Cell lysates were subjected to immunoprecipitation with anti-HA beads $(A)$ and analyzed by Western blotting using anti-HA (WB:HA) and anti-FLAG (WB:FLAG). One twenty-fifth of the load (L) and supernatant (S) were separated on the gel (lanes 1, 2 and 4) compared with half of the beads (B) (lanes 3 and 5).

Figure 1 Specific interactions of the MR with PIAS3 proteins in mammalian two-hybrid assays. (A) SK-N-MC cells seeded into 24-well plates were transfected with $125 \mathrm{ng}$ PIAS expression vectors in pVP16, expression vectors of the AF1 region (amino acids 170-433) of MR in pM, and pFR-Luc reporter plasmid; $50 \mathrm{ng}$ pCMV- $\beta$ gal were added as internal control. After $24 \mathrm{~h}$, cells were harvested and luciferase activity measured and normalized to $\beta$-gal and protein concentrations. 'Relative luciferase activity' represents the luciferase activity generated when cells were transfected with PIAS fusion proteins and the AF-1 domain of the MR relative to the luciferase activity observed when PIAS proteins were transfected with empty $\mathrm{pM}$ vectors. Each bar represents the mean \pm S.E.M. of three individual experiments done in triplicate. (B) SK-N-MC cells were grown in six-well plates and transfected with $625 \mathrm{ng}$ of each DNA. Protein extracts were prepared and levels of expressed protein determined by Western blotting using anti-VP16 antibody. (C) Transfection was performed as described above using the full-length MR as bait. Cells were treated for $24 \mathrm{~h}$ with either ALDO $\left(10^{-6} \mathrm{M}\right)$ and/or SPIRO $\left(10^{-5} \mathrm{M}\right.$, added $2 \mathrm{~h}$ before ALDO). Values shown are means \pm S.E.M. of three independent experiments performed in triplicate. 
A

\section{A/B domain of GR}

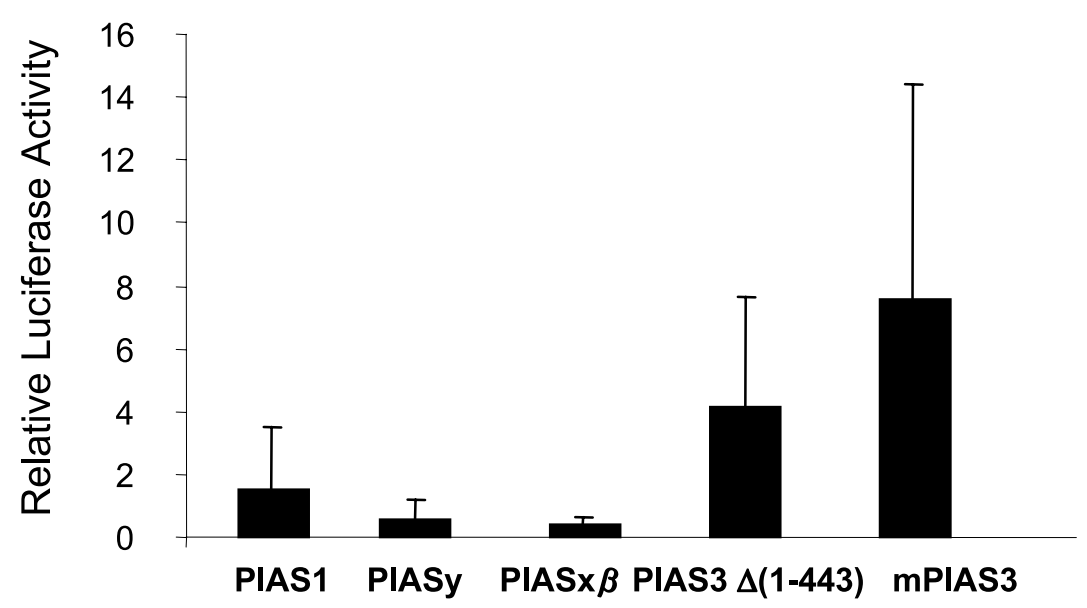

B
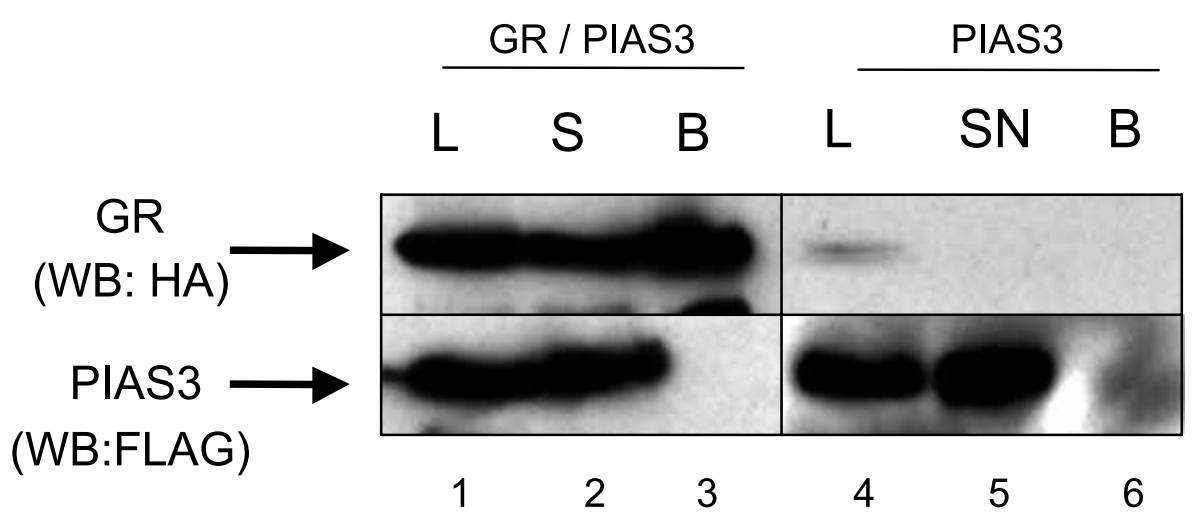

C
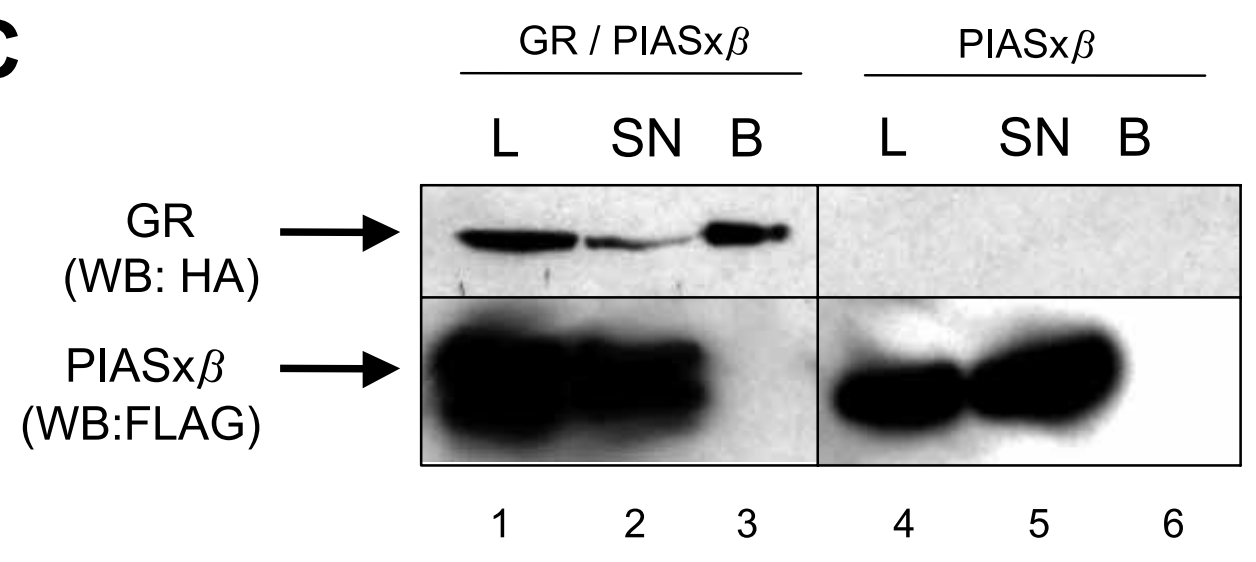
with other transcription factors, such as STAT-1 (Liao et al. 2000) and transcription intermediary factor-2 (TIF-2) (Jimenez-Lara et al. 2002).

\section{Analysis of PIAS protein-GR interactions in mammalian cells}

The AF-1 region of GR was fused to the DNA-binding domain of the GAL4 protein and used in mammalian two-hybrid assays as described in Fig. 1A; the results of these experiments are depicted in Fig. 3. As noted before, only PIAS3 showed a significant level of interaction with the N-terminal region of the GR (Fig. 3A). Full-length PIAS3 tended to show a stronger interaction with the GR than did PIAS $3 \Delta_{1-443}$, suggesting that a region(s) additional to the Ser/Ac domain of PIAS3 is(are) needed for GR association. The PIAS3GR interaction was not confirmed by coimmunoprecipitation experiments (Fig. 3B, lanes 1-3 are from lysates containing PIAS 3 and GR; cf. lysates containing only PIAS 3 are shown in lanes 4-6), demonstrating only a weak interaction of PIAS3 with GR. In confirmation of our observations in the mammalian two-hybrid assay, PIASx $\beta$ did not co-immunoprecipitate with GR (Fig. 3C, lanes 1-3 are from lysates containing PIASx $\beta$ and GR; cf. lysates containing only PIASx $\beta$ are shown in lanes 4-6).

\section{PIAS1, PIAS3 and PIASx $\beta$ repress the transcriptional activity of MR in SK-N-MC cells}

Transient transfection experiments to evaluate whether the isolated PIAS proteins can modulate the transcriptional activity of MR were carried out by co-transfecting SK-N-MC cells with MR and increasing amounts of each PIAS expression plasmid together with the MMTV reporter; cells were treated with $1 \mu \mathrm{M}$ ALDO and luciferase activities were determined $24 \mathrm{~h}$ later. While none of the PIAS proteins affected MR-driven transcription in the absence of hormone (data not shown), under basal conditions (Fig. 4A), all PIAS proteins, except for PIASy, suppressed the transcriptional activity of ALDO-stimulated MR in a dosedependent manner. Generally, the overexpression of PIAS proteins did not influence expression levels of MR protein (Fig. 4B). However, expression of PIASx $\beta$ resulted in a minor effect on MR levels and this change was not matched by a commensurate enhancing effect of PIASx $\beta$ on MR transactivation. Moreover, none of the PIAS proteins were able to modulate the activity of the unrelated CMV promoter (Fig. 4G), indicating that the observed inhibition of MR activity was not due to competition for basic transcription factors. The fact that PIAS1 and PIASx $\beta$ exerted effects on the transcriptional activity of MR comparable with those observed with PIAS3 is intriguing given that PIAS 1 and PIASx $\beta$, in contrast to PIAS3, did not show any appreciable interaction with MR in this system (cf. Figs 1 and 2); these findings are in line with other observations indicating that PIAS proteins can influence the activity of a large number of molecules involved in transcription through diverse mechanisms. Collectively, while the above experiments do not rule out transient and highly dynamic, direct interactions between PIAS 1 and PIASx $\beta$ proteins with MR, they clearly show that the transcriptional activity of MR can be compromised by the presence of increased levels of PIAS1, PIAS3 or PIASx $\beta$.

\section{Disparate effects of PIAS proteins on the transcriptional activity of GR}

GR closely resembles MR in terms of sequence and DNA-binding characteristics and, in many brain regions, these two receptors are often expressed by the same cell. Importantly, however, the activation

Figure 3 PIAS3 interacts weakly with the N-terminus region of the GR. (A) SK-N-MC cells seeded into 24-well plates were transfected with $125 \mathrm{ng}$ PIAS expression vectors in pVP16, expression vectors of the AF-1 region of GR in pM, and pFR-luc reporter plasmid; $50 \mathrm{ng}$ pCMV-Bgal were added as internal control. After $24 \mathrm{~h}$, cells were harvested and luciferase activity measured and normalized to $\beta$-gal and protein concentrations. 'Relative luciferase activity' was calculated as in Fig. 1. Each bar represents the mean \pm S.E.M. of three individual experiments done in triplicate. (B and C) SK-N-MC cells were transfected with $1.5 \mu \mathrm{g}$ of each of pCMV-HA-GR and pFLAG-mPIAS3 (B) or pCMV-HA-GR and $\mathrm{pFLAG-PIAS \times} \beta(C)$ expression vectors. $\mathrm{pCMV-FLAG2} \mathrm{was} \mathrm{used} \mathrm{to} \mathrm{keep} \mathrm{levels} \mathrm{of} \mathrm{total} \mathrm{transfected} \mathrm{DNA} \mathrm{constant.}$ Cell lysates were subjected to immunoprecipitation with anti-HA beads and analyzed by Western blotting using anti-HA (WB:HA) and anti-FLAG (WB:FLAG). One twenty-fifth of the load (L) and supernatant (S) were separated on the gel (lanes 1, 2, 4 and 5) compared with half of the beads (B) (lanes 3 and 6). 
A

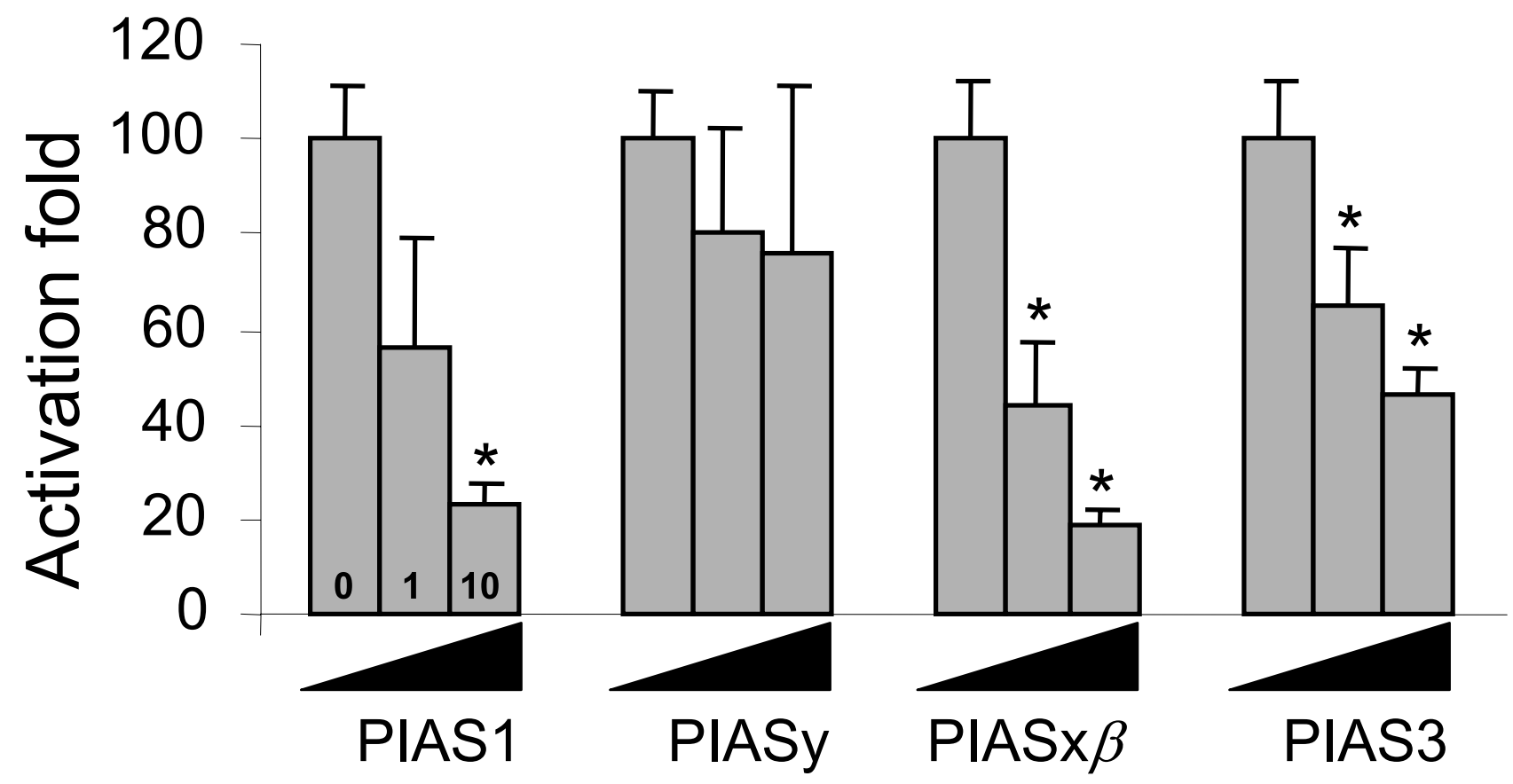

B

MR $\alpha$-tubulin

\section{MR
ulin}

C CMV-luciferase

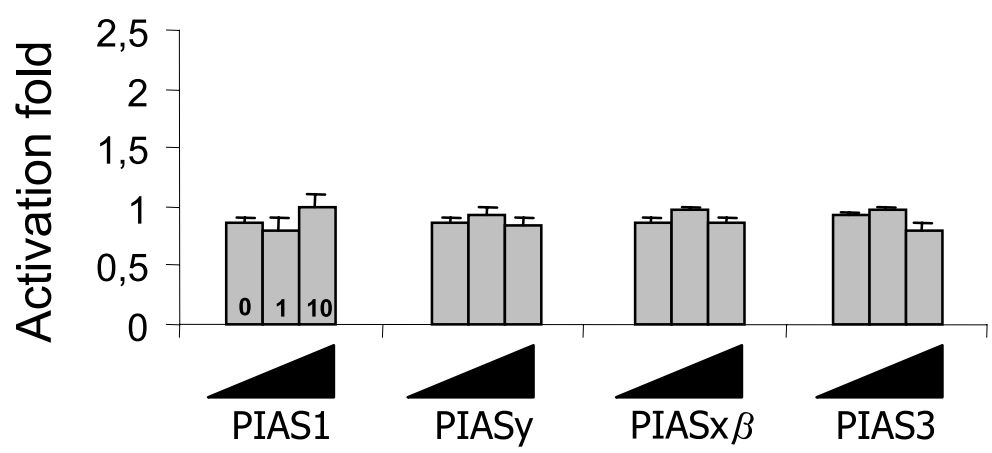


of GR in several cases results in effects opposite to those elicited by the stimulation of MR. Since PIAS proteins can up- or down-regulate the activities of various transcription factors, including nuclear receptors (Janne et al. 2000, Gross et al. 2001, Megidish et al. 2001, Sachdev et al. 2001, Schmidt \& Muller 2002), we considered it of interest to examine the effects of these proteins on the transcriptional activity of GR in the same cellular milieu in which their influence on MR activity was analyzed. To this end, SK-N-MC cells were co-transfected with a GR expression vector together with the MMTV-luciferase reporter in the presence of increasing amounts of the individual PIAS expression plasmids and exposed to the GR agonist DEX $(1 \mu \mathrm{M})$; luciferase activities were determined $24 \mathrm{~h}$ later. As reported here for the MR, the PIAS proteins did not affect basal activity of the GR. The results, depicted in Fig. 5A, show the effects of PIAS proteins on GR activity to be quite distinct from their effects on MR-triggered transcription in several respects (cf. Fig. 4A). PIAS 1 was found to significantly inhibit the transcriptional activity of GR $(P \leq 0 \cdot 05)$, resembling its effects on MR activity (cf. Fig. 4A). In contrast, PIAS3 did not influence GR activity, whereas both PIASx $\beta$ and PIASy significantly enhanced GR-mediated transcription $(P \leq 0 \cdot 05)$. Although PIAS3 interacted with GR weakly in the mammalian two-hybrid assays, such an interaction was not confirmed by co-immunoprecipitation experiments. This observation suggests a role for PIAS3 that is not confined to the modulation of steroid receptor-mediated transcription. Control experiments showed that the overexpression of PIAS proteins did not alter the levels of the transfected GR protein (Fig. 5B) or CMV promoter activity (Fig. 5C). Collectively, the data shown in Figs 4 and 5 demonstrate that, within the same cell type, PIAS proteins can alter the transactivation properties of $\mathrm{MR}$ and GR in distinct manners.

\section{Discussion}

In seeking a better understanding of the opposing actions mediated by MR and GR, four members of the PIAS family of proteins were isolated in a yeast two-hybrid screen using a portion of the AF-1 region of the MR as a bait. PIAS proteins were first discovered as inhibitors of activated STATs (Chung et al. 1997, Liu et al. 1998), but have since been found to also serve as binding partners and modulators of numerous transcriptional regulators (Junicho et al. 2000, Kotaja et al. 2000, Rodel et al. 2000, Gross et al. 2001, Zentner et al. 2001, Jimenez-Lara et al. 2002, Levy et al. 2002).

Mammalian two-hybrid assays and coimmunoprecipitation experiments in human neuroblastoma SK-N-MC cells with co-expressed tagged proteins revealed that only PIAS3 interacted strongly with the MR; PIAS3 interacted only weakly with the GR in our system. The association of PIAS3 with MR required the full-length protein, suggesting communication between different MR domains which, in turn, can determine the efficiency with which MR can physically associate with other proteins. This notion was further supported by the fact that the PIAS3-MR interaction was enhanced in the presence of the MR agonist ALDO but was not influenced by SPIRO, an MR antagonist which does not interfere with the entry of MR into the nucleus (M Tirard, unpublished observations). This

\footnotetext{
Figure 4 PIAS1, PIASx $\beta$ and PIAS3, but not PIASy, act as co-regulators of MR. (A) SK-N-MC cells grown in 24-well plates were transiently transfected with $125 \mathrm{ng}$ pMMTV-Luc reporter vectors and pRShMR together with $50 \mathrm{ng}$ pCMV- $\beta$ gal as internal control and increasing amounts of PIAS expression vectors (1-10 ng). An empty pCMV-HA vector was used to keep levels of total transfected DNA constant. After $12 \mathrm{~h}$, cells were treated with ALDO $\left(10^{-6} \mathrm{M}\right)$ for $12 \mathrm{~h}$ after which luciferase assays were performed. Luciferase activity was normalized with respect to $\beta$-gal activity and protein concentration. Results (mean \pm S.E.M. of 3-5 experiments) are expressed as induction-fold relative to the luciferase activity displayed in the absence of hormone. Induction-fold observed when cells were transfected with empty pCMV-HA (in the absence of PIAS) was set as 100. Asterisks indicate $P \leq 0.05$. (B) SK-N-MC cells grown in six-well plates were transfected with five times more DNA than in the study depicted in (A); other treatments and measurements were as described above. Proteins were immunoblotted with anti-EGFP to detect MR; $\alpha$-tubulin served as an internal control. (C) Cells were transfected with $125 \mathrm{ng}$ pCMV-luciferase and pRShMR expression vector together with increasing amounts of PIAS expression vectors (1-10 ng) and $50 \mathrm{ng} \mathrm{pCMV}$ - $\beta$ gal as internal control. An empty PCMV-HA vector was used to keep levels of total transfected DNA constant. Cells were treated and luciferase measurements made as indicated before.
} 
A

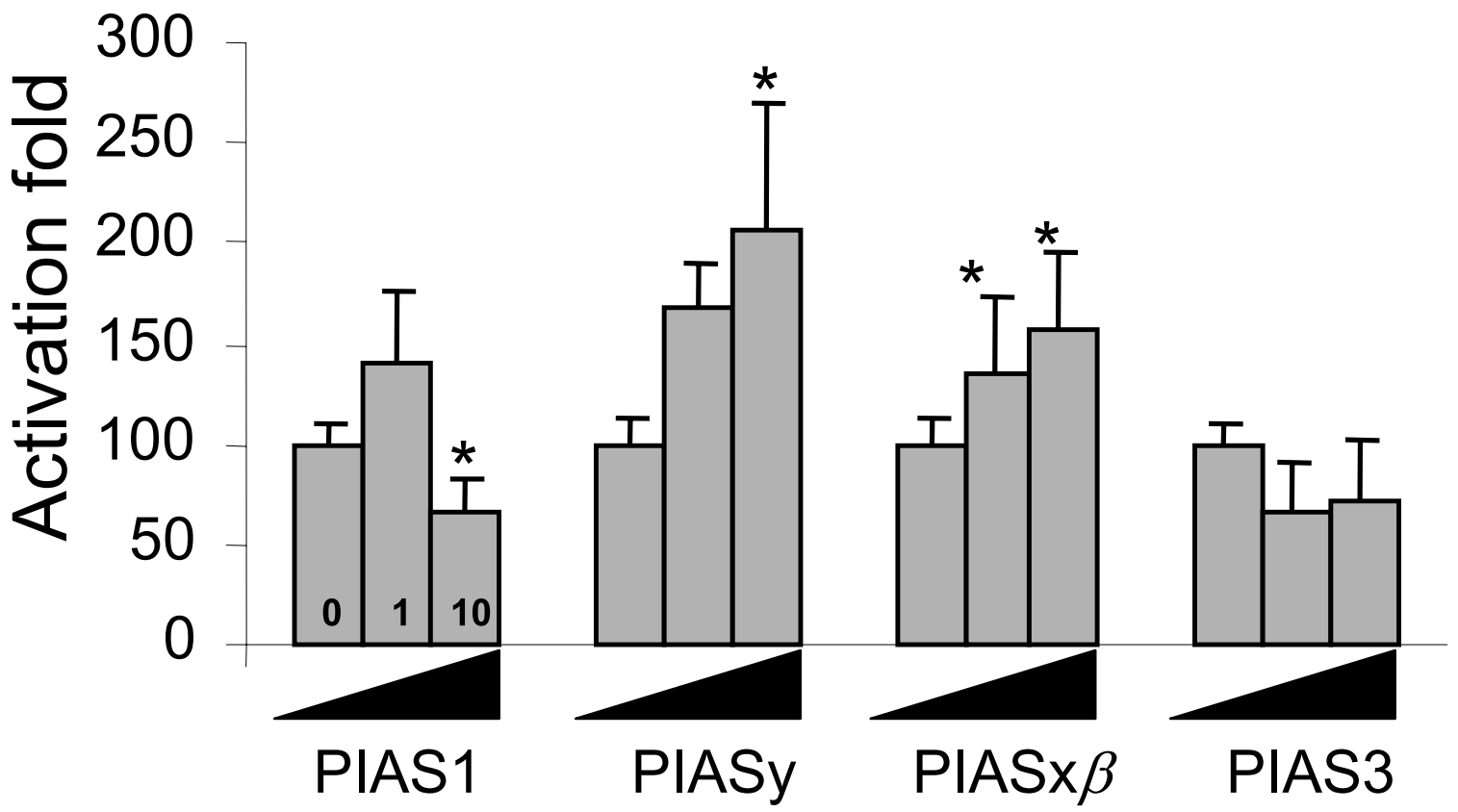

B

GR
$\alpha$-tubulin

CMV-luciferase

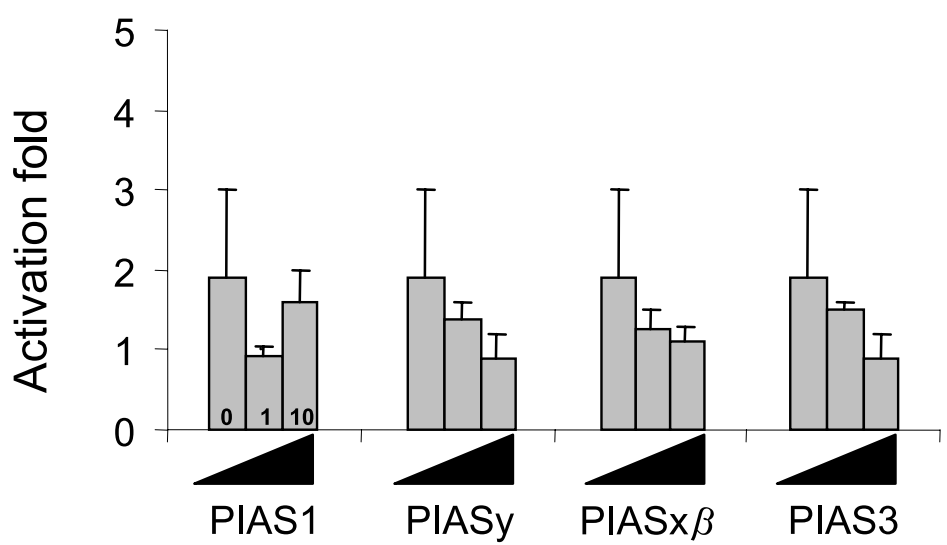


observation indicates that ALDO induces specific conformational changes in the receptor, allowing for a stronger interaction between the two proteins. Indeed, an interaction between the $\mathrm{N}$ - and the C-terminal regions of steroid hormone receptors has been previously described (Zhou et al. 1995, Tetel et al. 1999, Metivier et al. 2001, Thompson et al. 2001, He et al. 2002). Recently, an ALDOdependent interaction between the N-terminal domain of the MR with the hinge region and the ligand-binding domain was demonstrated (Rogerson \& Fuller 2003); this interaction was blocked by SPIRO, reminiscent of our observations. These authors further showed that this intramolecular interaction is not dependent on co-activators (e.g. SRC-1 and TIF-2) that bind to AF-2. The functional significance of cross-talk between the $\mathrm{N}$ - and $\mathrm{C}$-terminal regions of $\mathrm{MR}$ is not clear at present; however, our findings suggest that this interaction may provide novel surfaces which may be involved in the selective recruitment of modulatory molecules like PIAS3, or other transcriptional regulators such as the CREB-binding protein $(\mathrm{CBP}) /$ RNA helicase A-containing co-activator complex which also binds to the AF- 1 region of the MR, in a ligand-dependent manner (Kitagawa et al. 2002).

The interaction of PIAS3 with MR in SK-N-MC cells was retained when a clone lacking the first 443 amino acids was tested, indicating that MR interacts with sequences residing within the 176 G-terminal amino acid residues of PIAS3. This portion of the protein, which contains a characteristic Ser/Ac domain present in all members of the PIAS family (Liu et al. 1998), is responsible for the association of PIAS3 with other transcriptional regulators, such as interferon regulatory factor-1 (Nakagawa \& Yokosawa 2002) and TIF-2 (JimenezLara et al. 2002). In addition, the corresponding region of PIAS 1 protein has been previously shown to mediate the interaction with STAT-1 and to be necessary for the inhibition of STAT-1 activity (Liao et al. 2000). Likewise, the C-terminal region of PIASxa/ARIP3 was found to be sufficient for interaction with the androgen receptor (AR) in yeast whereas its deletion abolishes the ability of the protein to modulate AR-dependent transcription on minimal or complex promoters (Kotaja et al. 2002a). Our experiments do not rule out the possibility that other PIAS3 regions also interact with the MR; however, together with the above observations, they suggest that the conserved Ser/Ac domain might serve as a universal, non-selective anchoring surface for a variety of transcriptional regulators. Interactions may be stabilized and/or modulated through the involvement of other regions of the modular PIAS proteins, e.g. the LXXLL motifs (Liu et al. 2001, Kotaja et al. 2002b), the SAP module (Aravind \& Koonin 2000) or the SP-RING domain (Kahyo et al. 2001). While the last 176 amino acids of the C-terminus of PIAS3 are sufficient for its interaction with MR, our results show that the PIAS3-GR interaction may require other PIAS3 domains since full-length PIAS3 interacts more strongly than truncated PIAS3 (PIAS3 $\Delta_{1-443}$ ) in mammalian two-hybrid experiments. Interestingly, significant sequence divergence among the PIAS proteins is observed downstream of the Ser/Ac domain; the $\mathrm{C}$-terminal regions are the least conserved in the family (Liu et al. 1998). Whether these regions contribute to the specificity or efficacy of the PIAS interactions with other cellular proteins remains to be determined.

In transient transfection experiments in SKN-MC cells, PIAS3 was found to inhibit MR activity. Despite the fact that only PIAS3 displayed

Figure 5 Disparate effects of PIAS proteins on the transcriptional activity of GR. (A) SK-N-MC cells grown in 24-well plates were transiently transfected with $125 \mathrm{ng}$ pMMTV-Luc reporter vectors and $50 \mathrm{ng}$ pRShGR together with $50 \mathrm{ng}$ pCMV- $\beta$ gal as internal control and increasing amounts of PIAS expression vectors, as indicated in the Figure. Empty pCMV-HA vector was used to keep levels of total transfected DNA constant. After $12 \mathrm{~h}$ expression, cells were treated for $12 \mathrm{~h}$ with $10^{-6} \mathrm{M} \mathrm{DEX}$, luciferase activity measured and normalized to $\beta$-gal activity and protein concentrations. Results (means \pm S.E.M. from 3-5 experiments) are expressed as induction-fold relative to the luciferase activity displayed in the absence of hormone. Induction fold observed when cells were transfected with empty pCMV-HA was set as 100. Asterisks indicate $P \leq 0 \cdot 05$. (B) SK-N-MC cells grown in six-well plates were transfected with five times more DNA than in the study depicted in (A). Treatments and luciferase measurements were performed as described above. Proteins were immunoblotted with anti-GR; $\alpha$-tubulin served as an internal control. (C) Cells were transfected with $125 \mathrm{ng}$ pCMV-luciferase and pRShGR expression vector with increasing amounts of PIAS expression vectors (1-10 ng), together with $50 \mathrm{ng}$ pCMV- $\beta$ gal as internal control. An empty pCMV-HA vector was used to keep levels of total transfected DNA constant. All treatments and measurements were done as described before. 
a detectable interaction with MR, PIAS1 and PIASx $\beta$ also repressed MR activity, with the inhibition induced by PIASx $\beta$ being stronger than that seen with PIAS3. Interestingly, parallel co-transfection experiments using GR, in the same neural cell environment, showed that PIAS1 can also repress the transcriptional activity of GR in response to DEX. In contrast to MR, both PIASx $\beta$ and PIASy potentiated GR transactivation whereas PIAS3, which inhibited MR transactivation, had no effect on the GR response. Our findings strongly suggest that PIAS proteins mediate the differential regulation of the two corticosteroid receptors within the same neural milieu; their hereindescribed disparate effects on the transcriptional properties of MR and GR are consistent with earlier observations demonstrating that PIAS proteins can modulate steroid receptor-dependent transcriptional activation in different manners (Kotaja et al. 2000, Tan et al. 2002). It is pertinent to mention that the effects of these proteins are known to be influenced by various parameters, such as cell type and target enhancers/promoters as well as by the relative concentrations of the individual PIAS proteins in the cell. For example, the co-regulatory effects of PIAS1 on the AR were found to be modulated by co-expression of PIASx $\beta$ or PIASy whereas PIAS1 could associate directly with other members of the PIAS family (Tan et al. 2002). Such interplay among the PIAS proteins, but possibly also between PIAS and other cellular proteins, may explain their manifold effects on the transcriptional activity of corticosteroid receptors.

How do PIAS 1 and PIASx $\beta$ modulate MR transactivation without physically interacting with the receptor, and why does PIAS3 not influence the transactivation properties of the GR with which it associates? Besides their modulatory effects on the action of various transcription factors, PIAS proteins can also act as E3 SUMO (small ubiquitin-like modifier) ligases. 'Sumoylation' is involved in mediating protein-protein interactions in a variety of cellular processes, including protein stability, subcellular compartmentalization, chromatin structure and transcriptional regulation (for reviews see Muller et al. 2001, Pichler \& Melchior 2002, Verger et al. 2003). Several transcription factors, e.g. GR (Le Drean et al. 2002, Tian et al. 2002), AR (Tan et al. 2000, Nishida \& Yasuda 2002), progesterone receptor (PR) (Chauchereau et al. 2003), p53 and c-Jun (Rodriguez et al. 1999,
Muller et al. 2000) and IкB $\alpha$ (Desterro et al. 1998), are covalently modified by SUMO. PIAS proteins also associate with Ubc9 (ubiquitin-conjugating enzyme 9), a SUMO E2-activating enzyme (Kotaja et al. 2002a); further, self-sumoylation of PIAS proteins has been demonstrated (Nakagawa \& Yokosawa 2002, Kotaja et al. 2002a, Schmidt \& Muller 2002). Interestingly, Ubc9 and SUMO-1 were also isolated in our yeast two-hybrid screening as MR-interacting partners, strengthening the view that PIAS proteins may promote MR sumoylation. Recent studies have shown that the GR is subject to sumoylation (Le Drean et al. 2002, Tian et al. 2002), and our preliminary results strongly indicate that that MR can also be sumoylated in SK-N-MC cells (M Tirard, unpublished observations). During revision of this manuscript, an elegant study from Lombès' group (Tallec et al. 2003) reported that the MR can be sumoylated in vitro and in HeLa cells, thus confirming our ongoing work.

The synergy control (SG) motif was first identified in the N-terminal region of GR (Iniguez-Lluhi \& Pearce 2000) as a negative regulatory element. This sequence blocks synergistic activity resulting from cooperative DNA-binding of a transcription factor to multiple DNA response elements. The SC motif is identical to the binding motif of SUMO-1 $(\Psi \mathrm{KxE}$, where $\Psi$ is hydrophobic, and $\mathrm{x}$ any amino acid) and is also present in the N-terminal part of MR, a region that can prevent MR from self-synergizing at multiple response elements and interferes with the synergistic properties of GR on composite promoters (Pearce \& Yamamoto 1993, Rupprecht et al. 1993, Liu et al. 1995, Derfoul et al. 2000). As noted above, a recent study showed that mutation of the SUMO/SG motif enhances MR transactivation on a composite promoter (Tallec et al. 2003). Suggesting that this mechanism may apply to other NR also, is the recent observation that SUMO has a repressive effect on $\mathrm{PR}$ activity (Abdel-Hafiz et al. 2002); in the latter study, SUMO was found to require the liganded $\mathrm{C}$-terminal hormone-binding domain of $\mathrm{PR}$, implying communication between the $\mathrm{N}$ - and $\mathrm{C}$-termini (cf. the present findings for the ligand-enhanced interaction of PIAS3 with the MR). PIAS proteins can themselves be sumoylated and promote attachment of SUMO to MR and/or GR; they are also known to facilitate sumoylation of the co-regulators SRC-1 (Chauchereau et al. 2003) and TIF-2 (Jimenez-Lara et al. 2002, Kotaja 
et al. 2002a,b) and of histone deacetylases (David et al. 2002, Arora et al. 2003, Girdwood et al. 2003, Long et al. 2003). Therefore, PIAS proteins could determine the specific, step-wise assembly of proteins on target promoters, conferring specificity to transcription signals (cf. Kahyo et al. 2001, Schmidt \& Muller 2002).

The Introduction referred to the contrasting brain actions mediated by MR and GR and pointed out the similarities between the two receptors at the molecular level. The present work highlights the importance of several members of the PIAS family in the differential modulation of MR- and GR-mediated transcription, providing new insights into the mechanisms by which these two receptors may exert their distinct effects in the brain.

\section{Acknowledgements}

We would like to thank Drs Barbara Demeneix (National Museum of Natural History, Paris), Frauke Melchior and Andrea Pichler (Max Planck Institute of Biochemistry, Martinsried) for interest and support and critical comments on the manuscript. We also thank Drs Ron Evans (Salk Institute, La Jolla), Hinrich Gronemeyer (JGBMC, Strasbourg) and Jorma Palvimo (University of Helsinki, Finland) for generously providing various plasmids, and Dieter Fischer for technical support. Drs Theo Rein and Dietmar Spengler (Max Planck Institute of Psychiatry, Munich) kindly provided cells, reagents and valuable discussions. This work was partly supported through an FP5 Key Action Neuroscience Project Grant from The European Commission (Contract QLG3-2000-00844).

\section{References}

Abdel-Hafiz H, Takimoto GS, Tung L \& Horwitz KB 2002 The inhibitory function in human progesterone receptor $\mathrm{N}$ termini binds SUMO-1 protein to regulate autoinhibition and transrepression. Fournal of Biological Chemistry 277 33950-33956.

Almeida OFX, Conde GL, Crochemore C, Demeneix BA, Fischer D, Hassan AH, Meyer M, Holsboer F \& Michaelidis TM 2000 Subtle shifts in the ratio between pro and antiapoptotic molecules after activation of corticosteroid receptors decide neuronal fate. FASEB Fournal 14 779-790.

Aravind L \& Koonin EV 2000 SAP - a putative DNA-binding motif involved in chromosomal organization. Trends in Biochemical Sciences $25112-114$

Arora T, Liu B, He H, Kim J, Murphy TL, Murphy KM, Modlin RL \& Shuai K 2003 PIASx is a transcriptional co-repressor of signal transducer and activator of transcription 4. Fournal of Biological Chemistry 278 21327-21330.

Arriza JL, Weinberger C, Cerelli G, Glaser TM, Handelin BL, Housman DE \& Evans RM 1987 Cloning of human mineralocorticoid receptor complementary DNA: structural and functional kinship with the glucocorticoid receptor. Science $\mathbf{2 3 7}$ 268-275.

Chauchereau A, Amazit L, Quesne M, Guiochon-Mantel A \& Milgrom E 2003 Sumoylation of the progesterone receptor and of the steroid receptor coactivator SRC-1. Fournal of Biological Chemistry 278 12335-12343.

Chung CD, Liao J, Liu B, Rao X, Jay P, Berta P \& Shuai K 1997 Specific inhibition of Stat3 signal transduction by PIAS3. Science 278 1803-1805.

David G, Neptune MA \& DePinho RA 2002 SUMO-1 modification of histone deacetylase 1 (HDAC1) modulates its biological activities. Fournal of Biological Chemistry 277 23658-23663.

DeFranco DB 2002 Navigating steroid hormone receptors through the nuclear compartment. Molecular Endocrinology 16 1449-1455.

Derfoul A, Robertson NM, Hall DJ \& Litwack G 2000 The $\mathrm{N}$-terminal domain of the mineralocorticoid receptor modulates both mineralocorticoid receptor- and glucocorticoid receptormediated transactivation from $\mathrm{Na} / \mathrm{K}$ ATPase betal target gene promoter. Endocrine 13 287-295.

Desterro JM, Rodriguez MS \& Hay RT 1998 SUMO-1 modification of IkappaB alpha inhibits NF-kappaB activation. Molecular Cell $\mathbf{2}$ 233-239.

Girdwood D, Bumpass D, Vaughan OA, Thain A, Anderson LA, Snowden AW, Garcia-Wilson E, Perkins ND \& Hay RT 2003 P300 transcriptional repression is mediated by SUMO modification. Molecular Cell 11 1043-1054.

Glass CK \& Rosenfeld MG 2000 The coregulator exchange in transcriptional functions of nuclear receptors. Genes and Development 14 121-141.

Govindan MV \& Warriar N 1998 Reconstitution of the N-terminal transcription activation function of human mineralocorticoid receptor in a defective human glucocorticoid receptor. Fournal of Biological Chemistry 273 24439-24447.

Gronemeyer H \& Laudet V 2002 The Nuclear Receptor Facts Book. San Diego, CA: Academic Press, 462 pp.

Gross M, Liu B, Tan J, French FS, Carey M \& Shuai K 2001 Distinct effects of PIAS proteins on androgen-mediated gene activation in prostate cancer cells. Oncogene 20 3880-3887.

He B, Lee LW, Minges JT \& Wilson EM 2002 Dependence of selective gene activation on the androgen receptor $\mathrm{NH}_{2}$ - and COOH-terminal interaction. Fournal of Biological Chemistry 277 25631-25639.

Hochstrasser M 2001 SP-RING for SUMO: new functions bloom for a ubiquitin-like protein. Cell $\mathbf{1 0 7} 5-8$.

Hollenberg SM, Giguere V, Segui P \& Evans RM 1987 Colocalization of DNA binding and transcriptional activation functions in the human glucocorticoid receptor. Cell 49 39-46.

Iniguez-Lluhi JA \& Pearce D 2000 A common motif within the negative regulatory regions of multiple factors inhibits their transcriptional synergy. Molecular and Cellular Biology 20 6040-6050.

Janne OA, Moilanen AM, Poukka H, Rouleau N, Karvonen U, Kotaja N, Hakli M \& Palvimo JJ 2000 Androgen-receptorinteracting nuclear proteins. Biochemical Society Transactions $\mathbf{2 8}$ 401-405.

Jimenez-Lara AM, Heine MJ \& Gronemeyer H 2002 PIAS3 (protein inhibitor of activated STAT-3) modulates the transcriptional activation mediated by the nuclear receptor coactivator TIF2. FEBS Letters 526 142-146.

Joëls M 2000 Modulatory actions of steroid hormones and neuropeptides on electrical activity in brain. European fournal of Pharmacology 405 207-216. 
Joëls M 2001 Corticosteroid actions in the hippocampus. Fournal of Neuroendocrinology 13 657-669.

Junicho A, Matsuda T, Yamamoto T, Kishi H, Korkmaz K, Saatcioglu F, Fuse H \& Muraguchi A 2000 Protein inhibitor of activated STAT3 regulates androgen receptor signaling in prostate carcinoma cells. Biochemical and Biophysical Research Communications 278 9-13.

Kahyo T, Nishida T \& Yasuda H 2001 Involvement of PIAS1 in the sumoylation of tumor suppressor p53. Molecular Cell 8 713-718.

Kitagawa H, Yanagisawa J, Fuse H, Ogawa S, Yogiashi Y, Okuno A, Nagasawa H, Nakajima T, Matsumoto T \& Kato S 2002 Ligand-selective potentiation of rat mineralocorticoid receptor activation function 1 by a CBP-containing histone acetyltransferase complex. Molecular and Cellular Biology 22 3698-3706.

de Kloet ER, Oitzl MS \& Joëls M 1999 Stress and cognition: are corticosteroids good or bad guys? Trends in Neurosciences $\mathbf{2 2}$ 422-426.

de Kloet ER, Vreugdenhil E, Oitzl MS \& Joëls M 1998 Brain corticosteroid receptor balance in health and disease. Endocrine Reviews 19 269-301.

Kotaja N, Aittomaki S, Silvennoinen O, Palvimo JJ \& Janne OA 2000 ARIP3 (androgen receptor-interacting protein 3) and other PIAS (protein inhibitor of activated STAT) proteins differ in their ability to modulate steroid receptor-dependent transcriptional activation. Molecular Endocrinology 14 1986-2000.

Kotaja N, Karvonen U, Janne OA \& Palvimo JJ $2002 a$ PIAS proteins modulate transcription factors by functioning as SUMO-1 ligases. Molecular and Cellular Biology 22 5222-5234.

Kotaja N, Vihinen M, Palvimo JJ \& Janne OA 2002b Androgen receptor-interacting protein 3 and other PIAS proteins cooperate with glucocorticoid receptor-interacting protein 1 in steroid receptor-dependent signaling. Fournal of Biological Chemistry 277 17781-17788.

Le Drean Y, Mincheneau N, Le Goff P \& Michel D 2002 Potentiation of glucocorticoid receptor transcriptional activity by sumoylation. Endocrinology 143 3482-3489.

Levy L, Neuveut C, Renard CA, Charneau P, Branchereau S, Gauthier F, Van Nhieu JT, Cherqui D, Petit-Bertron AF, Mathieu D et al. 2002 Transcriptional activation of interleukin-8 by beta-catenin-Tcf4. Fournal of Biological Chemistry 277 42386-42393.

Liao J, Fu Y \& Shuai K 2000 Distinct roles of the $\mathrm{NH}_{2}$ - and COOH-terminal domains of the protein inhibitor of activated signal transducer and activator of transcription (STAT) 1 (PIAS1) in cytokine-induced PIAS 1-Statl interaction. PNAS 97 5267-5272.

Liu B, Liao J, Rao X, Kushner SA, Chung CD, Chang DD \& Shuai K 1998 Inhibition of Statl-mediated gene activation by PIAS1. PNAS 95 10626-10631.

Liu B, Gross M, ten Hoeve J \& Shuai K 2001 A transcriptional corepressor of Statl with an essential LXXLL signature motif. PNAS 98 3203-3207.

Liu W, Wang J, Sauter NK \& Pearce D 1995 Steroid receptor heterodimerization demonstrated in vitro and in vivo. PNAS 92 12480-12484.

Long J, Matsuura I, He D, Wang G, Shuai K \& Liu F 2003 Repression of Smad transcriptional activity by PIASy, an inhibitor of activated STAT. PNAS 100 9791-9796.

Lowry OH, Rosebrough NJ, Farr AL \& Randall RJ 1951 Protein measurement with the Folin phenol reagent. Fournal of Biological Chemistry 193 277-283.

McGaugh JL \& Roozendaal B 2002 Role of adrenal stress hormones in forming lasting memories in the brain. Current Opinion in Neurobiology 12 205-210.

Megidish T, Xu JH \& Xu CW 2001 Activation of p53 by protein inhibitor of activated Statl (PIAS1). Fournal of Biological Chemistry 277 8255-8259.
Meijer OC 2002 Coregulator proteins and corticosteroid action in the brain. Fournal of Neuroendocrinology 14 499-505.

Metivier R, Penot G, Flouriot G \& Pakdel F 2001 Synergism between ERalpha transactivation function 1 (AF-1) and AF-2 mediated by steroid receptor coactivator protein-1: requirement for the AF-1 alpha-helical core and for a direct interaction between the N-and C-terminal domains. Molecular Endocrinology 15 1953-1970.

Muller S, Berger M, Lehembre F, Seeler JS, Haupt Y \& Dejean A 2000 c-Jun and p53 activity is modulated by SUMO-1 modification. Fournal of Biological Chemistry 275 13321-13329.

Muller S, Hoege C, Pyrowolakis G \& Jentsch S 2001 SUMO, ubiquitin's mysterious cousin. Nature Reviewes. Molecular and Cellular Biology 2 202-210.

Nakagawa K \& Yokosawa H 2002 PIAS3 induces SUMO-1 modification and transcriptional repression of IRF-1. FEBS Letters $530204-208$.

Nair SM, Werkman TR, Craig J, Finnell R, Joëls M \& Eberwine JH 1998 Corticosteroid regulation of ion channel conductances and mRNA levels in individual hippocampal CAl neurons. Fournal of Neuroscience 18 2685-2696.

Nishida T \& Yasuda H 2002 PIAS1 and PIASxalpha function as SUMO-E3 ligases toward androgen receptor and repress androgen receptor-dependent transcription. Fournal of Biological Chemistry 277 41311-41317.

Pearce D \& Yamamoto KR 1993 Mineralocorticoid and glucocorticoid receptor activities distinguished by nonreceptor factors at a composite response element. Science 259 1161-1165.

Pichler A \& Melchior F 2002 Ubiquitin-related modifier SUMO1 and nucleocytoplasmic transport. Traffic 3 381-387.

Reul JM \& de Kloet ER 1985 Two receptor systems for corticosterone in rat brain: microdistribution and differential occupation. Endocrinology $1172505-2511$.

Rodel B, Tavassoli K, Karsunky H, Schmidt T, Bachmann M, Schaper F, Heinrich P, Shuai K, Elsasser HP \& Moroy T 2000 The zinc finger protein Gfi-1 can enhance STAT3 signaling by interacting with the STAT3 inhibitor PIAS3. EMBO foumal 19 5845-5855.

Rodriguez MS, Desterro JM, Lain S, Midgley CA, Lane DP \& Hay RT 1999 SUMO-1 modification activates the transcriptional response of p53. EMBO Fournal 18 6455-6461.

Rogerson FM \& Fuller PJ 2003 Interdomain interactions in the mineralocorticoid receptor. Molecular and Cellular Endocrinology 200 45-55.

Roland BL, Krozowski ZS \& Funder JW 1995 Glucocorticoid receptor, mineralocorticoid receptors, 11 beta-hydroxysteroid dehydrogenase- 1 and -2 expression in rat brain and kidney: in situ studies. Molecular and Cellular Endocrinology 111 R1-R7.

Rosenfeld MG \& Glass CK 2001 Coregulator codes of transcriptional regulation by nuclear receptors. Fournal of Biological Chemistry 276 36865-36868.

Rupprecht R, Arriza JL, Spengler D, Reul JM, Evans RM, Holsboer F \& Damm K 1993 Transactivation and synergistic properties of the mineralocorticoid receptor: relationship to the glucocorticoid receptor. Molecular Endocrinology 7 597-603.

Sachdev S, Bruhn L, Sieber H, Pichler A, Melchior F \& Grosschedl R 2001 PIASy, a nuclear matrix-associated SUMO E3 ligase, represses LEF1 activity by sequestration into nuclear bodies. Genes and Development 15 3088-3103.

Schmidt D \& Muller S 2002 Members of the PIAS family act as SUMO ligases for c-Jun and p53 and repress p53 activity. PNAS $992872-2877$.

Sloviter RS, Sollas AL, Dean E \& Neubort S 1993 Adrenalectomy-induced granule cell degeneration in the rat hippocampal dentate gyrus: characterization of an in vivo model of controlled neuronal death. Fournal of Comparative Neurology 330 324-336. 
Sousa N \& Almeida OFX 2002 Corticosteroids: sculptors of the hippocampal formation. Reviews in the Neurosciences 13 59-84.

Tallec PL, Kirsh O, Lecomte M-C, Viengchareun S, Zennaro M-C, Dejean A \& Lombes M 2003 Protein inhibitor of activated signal transducer and activator of transcription 1 interacts with the $\mathrm{N}$-terminal domain of mineralocorticoid receptor and represses its transcriptional activity: Implication of small ubiquitinrelated modifier 1 modification. Molecular Endocrinology 17 2529-2542.

Tan JA, Hall SH, Hamil KG, Grossman G, Petrusz P, Liao J, Shuai K \& French FS 2000 Protein inhibitor of activated STAT-1 (signal transducer and activator of transcription-1) is a nuclear receptor coregulator expressed in human testis. Molecular Endocrinology 14 14-26.

Tan JA, Hall SH, Hamil KG, Grossman G, Petrusz P \& French FS 2002 Protein inhibitors of activated STAT resemble scaffold attachment factors and function as interacting nuclear receptor coregulators. Journal of Biological Chemistry 277 16993-17001.

Tetel MJ, Giangrande PH, Leonhardt SA, McDonnell DP \& Edwards DP 1999 Hormone-dependent interaction between the amino- and carboxyl-terminal domains of progesterone receptor in vitro and in vivo. Molecular Endocrinology 13 910-924.

Thompson J, Saatcioglu F, Janne OA \& Palvimo JJ 2001 Disrupted amino- and carboxyl-terminal interactions of the androgen receptor are linked to androgen insensitivity. Molecular Endocrinology 15 923-935.

Tian S, Poukka H, Palvimo JJ \& Janne OA 2002 Small ubiquitinrelated modifier-1 (SUMO-1) modification of the glucocorticoid receptor. Biochemical Fournal $\mathbf{3 6 7}$ 907-911.

Valdez BC, Henning D, Perlaky L, Busch RK \& Busch H 1997 Cloning and characterization of $\mathrm{Gu} / \mathrm{RH}-\mathrm{II}$ binding protein.
Biochemical and Biophysical Research Communications 234 335-340.

van Steensel B, van Binnendijk EP, Hornsby CD, van der Voort HT, Krozowski ZS, de Kloet ER \& van Driel R 1996 Partial colocalization of glucocorticoid and mineralocorticoid receptors in discrete compartments in nuclei of rat hippocampus neurons. Journal of Cell Science 109 787-792.

Verger A, Perdomo J \& Crossley M 2003 Modification with SUMO. A role in transcriptional regulation. EMBO Reports 4 137-142.

Wu L, Wu H, Ma L, Sangiorgi F, Wu N, Bell JR, Lyons GE \& Maxson R 1997 Mizl, a novel zinc finger transcription factor that interacts with Msx2 and enhances its affinity for DNA. Mechanisms of Development 65 3-17.

Xu J \& Li Q 2003 Review of the in vivo functions of the p160 steroid receptor coactivator family. Molecular Endocrinology 17 1681-1692.

Zentner MD, Lin HH, Deng HT, Kim KJ, Shih HM \& Ann DK 2001 Requirement for high mobility group protein HMGI-C interaction with STAT3 inhibitor PIAS3 in repression of alpha-subunit of epithelial $\mathrm{Na}^{+}$channel (alpha-ENaC) transcription by Ras activation in salivary epithelial cells. Fournal of Biological Chemistry 276 29805-29814.

Zhou ZX, Lane MV, Kemppainen JA, French FS \& Wilson EM 1995 Specificity of ligand-dependent androgen receptor stabilization: receptor domain interactions influence ligand dissociation and receptor stability. Molecular Endocrinology 9 208-218.

Received in final form 20 January 2004 Accepted 10 February 2004 